Published in Modern Intellectual History 15 (2018), 681-709. (C Cambridge University Press.

Online at https://doi.org/10.1017/S1479244317000142

\title{
The Virtues of a Good Historian in Early Imperial Germany: Georg Waitz's Contested Example $^{1}$
}

Herman Paul

Recent literature on the moral economy of nineteenth-century German historiography shares with older scholarship on Leopold von Ranke's methodological revolution a tendency to refer to "the" historical discipline in the third person singular. This would make sense as long as historians occupied a common professional space and/or shared a basic understanding of what it meant to be an historian. Yet, as this article demonstrates, in a world sharply divided over political and religious issues, historians found it difficult to agree on what it meant to be a good historian. Drawing on the case of Ranke's influential pupil Georg Waitz, whose death in 1886 occasioned a debate on the relative merits of the example that Waitz had embodied, this article argues that historians in early Imperial Germany were considerably more divided over what they called "the virtues of the historian" than has been acknowledged to date. Their most important frame of reference was not a shared discipline but rather a variety of approaches corresponding to a diversity of models or examples ("scholarly personae" in modern academic parlance), the defining features of which were often starkly contrasted. Although common ground beneath these disagreements was not entirely absent, the habit of late nineteenth-century German historians to position themselves between Waitz and Heinrich von Sybel, Ranke and Friedrich Christoph Dahlmann, or other pairs of proper names turned into models of virtue, suggests that these historians experienced their professional environment as characterized primarily by disagreement over the marks of a good historian.

\section{Introduction}

\footnotetext{
${ }^{1}$ Research for this article was made possible by a summer stay at the Max Planck Institute for the History of Science in Berlin. I would like to thank Lorraine Daston for her hospitality and advice, the editors of this journal and two anonymous reviewers for valuable suggestions, and the Netherlands Organization for Scientific Research (NWO) for generous funding.
} 
What does it take to be a good historian? When students of Georg Waitz, one of Germany's most influential scholars of medieval history, gathered in Göttingen in 1874 to celebrate the twenty-fifth anniversary of their teacher's historische Übungen, they gave a twofold answer to this question. One mark of a good historian as they defined him (not yet her) was that he belonged to the "Ranke family" by virtue of having received his training either from Leopold von Ranke or from one of Ranke's former students, of whom Waitz was by far the most productive in terms of the number of novices he initiated into the guild. ${ }^{2}$ Virtually all the speakers inscribed themselves in this genealogy by presenting themselves as "sons" of Waitz and "grandchildren of Ranke," who as one "large family" were gathered for a festive "family feast. ${ }^{\prime 3}$ Waitz himself, too, drew on familial resources in hailing the occasion as a "silver wedding feast" and in assuring his "sons," many of whom had meanwhile acquired teaching or research positions, that they had become "brethren" in the pursuit of historical studies. ${ }^{4}$ The genealogical chain was visualized by a marble bust of Ranke, created by Friedrich Drake and presented to Waitz as a tangible symbol of their familial bond. ${ }^{5}$

If family background was one means for identifying good historians, virtues and vices were another one. In specifying what membership of Ranke's family demanded in terms of professional conduct, all of Waitz's students invoked categories of virtue and vice. For them, historians were supposed to excel in virtues of the sort that Waitz had ascribed to Ranke: “criticism," "penetration," and "precision." ${ }^{6}$ They had learned from Ranke, among others, to

\footnotetext{
${ }^{2}$ Ulrich Muhlack, “Die Stellung von Georg Waitz in der deutschen Geschichtswissenschaft des 19. Jahrhunderts," in Bohumil Jiroušek, Josef Blüml, and Dagmar Blümlová, eds., Jaroslav Goll a jeho žáci (České Budějovice, 2005), 165-81; Wolfgang Weber, Priester der Kio: Historisch-sozialwissenschaftliche Studien zur Herkunft und Karriere deutscher Historiker und zur Geschichte der Geschichtswissenschaft 1800-1970 (Frankfurt am Main, 1984), 222-4. On Waitz's contributions to medieval history, including especially the history of law, see Robert L. Benson and Loren J. Weber, “Georg Waitz (1813-1886)," in Helen Damico and Joseph B. Zavadil, eds., Medieval Scholarship: Biographical Studies on the Formation of a Discipline, vol. 1 (New York, 1995), 63-75; Ernst-Wolfgang Böckenförde, Die deutsche verfassungsgeschichtliche Forschung im 19. Jahrhundert: Zeitgebundene Fragestellungen und Leitbilder (Berlin, 1961), 99-134.

${ }^{3}$ [Konstantin Höhlbaum], Die Jubelfeier der historischen Übungen zu Göttingen am 1. August 1874: Bericht des Fest-Comités (Göttingen, 1874), 7, 15. Unless otherwise noted, all translations are mine.

${ }^{4}$ Ibid., 7, 13.

${ }^{5}$ Ibid., 7-8.

${ }^{6}$ Ibid., 9; G. Waitz, Die historischen Übungen zu Göttingen: Glückwunschschreiben an Leopold von Ranke zum Tage der Feier seines fünfzigjährigen Doctorjubiläums, 20. Februar 1867 (Göttingen, 1867), 4.
} 
be "meticulously critical" and to aspire to "strict truthfulness" (strenger Wahrhaftigkeit). Waitz himself, who was said to embody a "spirit of truthfulness and righteousness," was held up as a model of "dedicated meticulousness," who expected from his students "total earnestness" and "persistent diligence.." For Waitz's pupils, a good historian apparently was adorned with virtuous dispositions, too.

Recent scholarship has uncovered this concern for virtues and vices as an important, yet understudied aspect of nineteenth-century historical studies (one with analogies, to be sure, in other disciplines and with centuries-old repertoires on which it could draw). ${ }^{8}$ While nineteenth-century German historiography in particular has often been analyzed in terms of historical methods promulgated by Ranke and his students, ${ }^{9}$ newer studies have shown that nineteenth-century historians were at least equally concerned about the molding of scholarly selves. Historians' repeated insistence on "love of truth," "loyalty," "accuracy," and "impartiality" conveys that they cared not only about research techniques, but also about dispositions or character traits that they saw as conducive to being a good historian dispositions they believed were cultivated and refined in Übungen like Waitz's. ${ }^{10}$ Some historians, such as the influential textbook author Ernst Bernheim, even came close to

\footnotetext{
${ }^{7}$ [Höhlbaum], Jubelfeier, 6.

${ }^{8}$ For the early modern roots of nineteenth-century scholarly virtue language, see Matthew L. Jones, The Good Life in the Scientific Revolution: Descartes, Pascal, Leibniz, and the Cultivation of Virtue (Chicago, 2006); Sorana Corneanu, Regimens of the Mind: Boyle, Locke, and the Early Modern Cultura Animi Tradition (Chicago, 2011); Sari Kivistö, The Vices of Learning: Morality and Knowledge at Early Modern Universities (Leiden, 2014); Kathryn Murphy and Anita Traninger, eds., The Emergence of Impartiality (Leiden, 2014); Chad Wellmon, Organizing Enlightenment: Information Overload and the Invention of the Modern Research University (Baltimore, MD, 2015).

9 E.g., Rolf Torstendahl, The Rise and Propagation of Historical Professionalism (New York, 2015); Jörn Rüsen, "Historische Methode," in Christian Meier and Jörn Rüsen, eds., Historische Methode (Munich, 1988), 62-80.

${ }^{10}$ E.g., Jo Tollebeek, Men of Character: The Emergence of the Modern Humanities (Wassenaar, 2011); Herman Paul, "The Scholarly Self: Ideals of Intellectual Virtue in Nineteenth-Century Leiden," in Rens Bod, Jaap Maat, and Thijs Weststeijn, eds., The Making of the Humanities, vol. 2 (Amsterdam, 2012), 397-411; Kasper Risbjerg Eskildsen, "Inventing the Archive: Testimony and Virtue in Modern Historiography," History of the Human Sciences, 26/4 (2013), 8-26.
} 
defining historical methods in terms of virtues, thereby implying that disagreement about virtues amounted to disagreement about methods. ${ }^{11}$

In line with this new path of research, Kasper Risbjerg Eskildsen interprets the WaitzFest as illustrating that historical research was understood "not only as a method, but also as an attitude to life." The virtue language favored by Waitz's pupils denoted character traits inherited from the Rankean tradition that they regarded as vital for the "moral economy" of historical scholarship. ${ }^{12}$ Similarly, Falko Schnicke regards the 1874 festivities as an exercise in scholarly community building. Focusing on the family metaphors used by Waitz's students, he argues that the historians created an "imagined community" centered around Ranke, whose marble bust served as a devotional image, allowing the assembled believers to identify collectively with the "true master of historical scholarship." ${ }^{13}$ In this reading, the virtues ascribed to Ranke and Waitz were not just individual character traits, but features of the collective body of the historical discipline. More precisely, to the extent that Ranke's body as immortalized in marble symbolized the collective body of German historical scholarship, membership of the historical profession required imitation of Ranke's alleged virtues. ${ }^{14}$ It almost seems, then, as if the two answers given in 1874 - a good historian is a son of Ranke and a man of virtue - were part and parcel of the same vision: scholarly virtues were character traits to be developed through identification with Ranke.

Yet how different was the picture that emerged twelve years later, when Waitz had died and obituary writers tried to assess the merits of the deceased. Although most obituary writers could locate themselves genealogically within the Ranke school, unanimity on virtues

\footnotetext{
${ }^{11}$ Herman Paul, “Distance and Self-Distanciation: Intellectual Virtue and Historical Method around 1900," History and Theory, Theme Issue 50 (2011), 104-16.

${ }^{12}$ Kasper Risbjerg Eskildsen, “Private Übungen und verkörpertes Wissen: Zur Unterrichtspraxis der Geschichtswissenschaft im neunzehnten Jahrhundert," in Martin Kintzinger and Sita Steckel, eds., Akademische Wissenskulturen: Praktiken des Lehrens und Forschens vom Mittelalter bis zur Moderne (Basel, 2015), 143-61, at 159, 161, under reference to Lorraine Daston, "The Moral Economy of Science," Orisis, 10 (1995), 2-24. Jo Tollebeek arrives at similar conclusions in his "Commemorative Practices in the Humanities around 1900," Advances in Historical Studies, 4 (2015), 216-31, at 217.

${ }^{13}$ Falko Schnicke, “Rituale der Verkörperung: Seminarfeste und Jubiläen der Geschichtswissenschaft des 19. Jahrhunderts," Zeitschrift für Geschichtswissenschaft, 63 (2015), 337-58, at 346; [Höhlbaum], Jubelfeier, 9. ${ }^{14}$ Falko Schnicke, Die männliche Disziplin: Zur Vergeschlechtlichung der deutschen Geschichtswissenschaft 1780-1900 (Göttingen, 2015), 213-14, 248.
} 
conducive to historical study simply didn't exist. While some hewed closely to Waitz's example, others wondered aloud whether Waitz hadn't been one-sided in privileging philological precision over grand vistas, artistic style, or healthy patriotism. Such criticism was unsurprising as long as it came from historians like Heinrich von Sybel, who was deeply concerned about colleagues severing old ties between history, literature, and politics for the sake of science (Wissenschaft). ${ }^{15}$ But even among Waitz's students, who by 1874 had seemed united in devotion to painstaking historical criticism, the death of their teacher occasioned a debate in which Waitz's model of virtue was consistently compared, positively or negatively, to alternative models embodied by other historians.

So how representative was the 1874 manifestation when it comes to standards of virtue among nineteenth-century German historians? Even if virtue language was ubiquitous, which hardly surprises in an educated middle class context used to framing moral demands in terms of virtue, ${ }^{16}$ could it be that different historians assigned different value to different virtues, depending on how they defined the historian's vocation? And if so, could it be the case that nineteenth-century German historiography was more divided over the marks distinguishing a good historian than assumed both in older studies on the methodological "paradigm" of German historicism and in newer, emerging research on historiographical virtues and vices?

Drawing on a rich body of obituaries written for Waitz, this article offers a more precise and more thoroughly contextualized analysis by arguing that the combination of Waitz's influence and recognizable profile made him a prime candidate for transformation into a clearly delineated model of what a virtuous historian might look like. ${ }^{17}$ Crucial is that

\footnotetext{
${ }^{15}$ Volker Dotterweich, Heinrich von Sybel: Geschichtswissenschaft in politischer Absicht (1817-1861) (Göttingen, 1978).

${ }^{16}$ Rudolf Schenda, “Die Verfleißigung der Deutschen: Materialien zur Indoktrination eines Tugend-Bündels," in Utz Jeggle et al., eds., Volkskultur in der Moderne: Probleme und Perspektiven empirischer Kulturforschung (Reinbek bei Hamburg, 1986), 88-108; Dieter Hein, “Arbeit, Fleiß und Ordnung," in Hans-Werner Hahn and Dieter Hein, eds., Bürgerliche Werte um 1800: Entwurf, Vermittlung, Rezeption (Cologne, 2005), 239-51; Manfred Hettling and Stefan-Ludwig Hoffmann, eds., Der bürgerliche Wertehimmel: Innenansichten des 19. Jahrhunderts (Göttingen, 2000).

${ }^{17}$ Obituaries were part of a richer set of commemorative practices and modes of memorialization, which in Waitz's case also included the aforementioned 1874 manifestation, a commemoration of his seventieth birthday in 1883, a photographic portrait by Bernhard Petri, a bust by Ferdinand Hartzer, and a Festschrift
} 
such models of virtue existed in the plural: Waitz's model derived its peculiar features mainly through contrast with alternative models, such as those associated with Friedrich Christoph Schlosser, Friedrich Christoph Dahlmann, Sybel, and Johannes Janssen. After examining how some of Waitz's students positioned both their teacher and themselves on an imaginary map of models, the article argues that these larger than life embodiments of virtue can profitably be regarded as "scholarly personae," given that they served as paradigms embodying dispositions of virtue that were deemed necessary for being an historian. Accordingly, Waitz's necrologies not only paid tribute to a deceased senior colleague, but more importantly also helped shape a scholarly persona to which historians could relate, positively or negatively, in articulating their own understanding of the historian's vocation.

The article concludes by emphasizing that such personae were commemorated not because they were universally accepted as models, but, to the contrary, because historians in the early decades of the German Empire, shortly after the Franco-Prussian War and the Kulturkampf, disagreed on how appropriate it was for historians to be of Jewish descent, to belong to the Roman Catholic Church, to identify patriotically with the German nation, or to counterbalance growing specialization by writing non-specialized history books for general readers. Given these disagreements, the praise heaped upon Waitz in 1874 and 1886 should not be mistaken for wide acclaim. Those supporting Waitz's model promoted a specific scholarly persona in a world profoundly divided over what it took to be a good historian.

\section{Waitz's obituaries}

The corpus of necrologies on which this article draws consists of 29 obituaries, short death announcements in German newspapers not included, which vary in length from a single paragraph to 53 pages. They come from six different countries - Germany, Switzerland, France, Spain, Sweden, and the Netherlands, with the Spanish one actually being authored by a German Hispanist - and are written in five different languages by 27 different authors

planned for the occasion of his fiftieth Doctorjubiläum. For the purposes of this article, however, obituaries are by far the richest source, as they alone comment explicitly on Waitz's perceived virtues and vices. On academic commemorative practices, see Tollebeek, "Commemorative Practices" and a theme issue of Osiris 14 (1999), edited by Pnina G. Abir-Am and Clark A. Eliott. On historians' portraits in nineteenth-century Germany, see Schnicke, Männliche Disziplin, 138-213. 
(Wilhelm von Giesebrecht and Alfred Stern wrote two obituaries each). ${ }^{18}$ At least ten of the obituary writers were former students of Waitz. ${ }^{19}$ In terms of confession, the group includes one Jewish (Stern) and two Catholic historians (Hermann Grauert and Georges Blondel), with all others having Protestant backgrounds. ${ }^{20}$ Eight obituaries appeared in newspapers such as the Allgemeine Zeitung, whereas many others were produced by local or regional historical associations. The corpus also includes necrologies read at the Prussian, Bavarian, and Göttingen academies of sciences as well as the Monumenta Germaniae Historica, the source editing project that Waitz had directed from 1875 to his death in 1886.

The number of necrologies testifies to Waitz's significance: few nineteenth-century German historians received more than a handful of obituaries. At the same time, Waitz's "burial in the newspapers" was not as grandiose as Ranke's or Sybel's, obituaries of whom virtually every German newspaper felt obliged to run. ${ }^{21}$ As a long-time member of the German Reichstag and the author of a best-selling Geschichte der Revolutionszeit von 1789 bis 1815 (5 vols., 1853-79), Sybel could be commemorated as a man of national significance - "a political historian or, if one wants, a history-writing politician." ${ }^{22}$ Ranke's star had risen even higher: the London Times ranked him among the greatest of his generation ("Had Germany a Pantheon or a Westminster Abbey, the remains of Leopold von Ranke would

\footnotetext{
${ }^{18}$ In the not implausible case that the anonymous necrology in "Bericht über die zwölfte Plenarversammlung der Central-Direction der Monumenta Germaniae, Berlin 1886," Neues Archiv der Gesellschaft für Ältere Deutsche Geschichtskunde, 12 (1887), 1-10, at 3-5 was written by Wilhelm Wattenbach, who also commemorated Waitz in the Berlin Academy of Sciences, the number of authors would shrink to 26.

${ }^{19}$ Based on the list of students included in Eberhard Waitz, Georg Waitz: Ein Lebens- und Charakterbild zu seinem hundertjährigen Geburtstag 9. Oktober 1913 (Berlin, 1913), 92-100.

${ }^{20}$ Not included in these statistics are five obituaries whose authors could not be identified, either because they appeared anonymously (Vossische Zeitung, Zeitung für das höhere Unterrichtswesen Deutschlands, Historisk Tidskrift, De Nederlandsche Heraut) or because they were signed with initials that cannot be attributed (Rostocker Zeitung).

${ }^{21}$ The expression comes from Sophie Weisse, “Leopold von Ranke: Reminiscences of Berlin, 1884-1885," Blackwood's Edinburgh Magazine, 140 (1886), 251-8, at 251. More than 150 newspaper obituaries of Sybel have been kept among his personal papers: Secret State Archives Prussian Cultural Heritage (Berlin), Nachlass Heinrich von Sybel, inv. nos. A19-21. For Ranke's obituaries, see Günter Johannes Henz, Leopold von Ranke in Geschichtsdenken und Forschung, vol. 1 (Berlin, 2014), 375-83.

22 “Heinrich v. Sybel," Hagener Zeitung (3 August 1895).
} 
certainly find a place in it"). ${ }^{23}$ Waitz's achievements, by contrast, were seen as limited to the realm of scholarship, despite his membership of the Frankfurt Parliament (1848-9) some forty years before. ${ }^{24}$ Accordingly, most of his obituaries were written by historians - which makes the source material well suited for the purposes of this article. ${ }^{25}$

Although the obituaries presented themselves under various names, such as Nachruf, Gedächtnisrede, Gedenkblatt, and Nekrologe, these labels did not correspond strictly to distinct necrological genres. ${ }^{26}$ Most obituaries followed a conventional "life and work" template focused on family background, formative experiences, influential teachers, career steps, and major accomplishments, followed by evaluative remarks. ${ }^{27}$ The ratio of these ingredients varied, however. Shorter obituaries, written for non-German or non-professional audiences, usually restricted themselves to biographical information, while historical associations often highlighted Waitz's pedagogical influence or practical help with editions of charters. ${ }^{28}$ Readers of women's magazine were treated to a homogenizing picture of Waitz

\footnotetext{
23 "Germany," The Times (25 May 1886).

${ }^{24}$ On which see Hermann Hagenah, “Georg Waitz als Politiker," Veröffentlichungen der SchleswigHolsteinischen Universitätsgesellschaft, 31 (1930), 134-217.

${ }^{25}$ In passing, this also explains why Waitz was spared human interest pieces on his home interior, day rhythm, and eating habits, such as written posthumously about Ranke and Sybel: Waitz was too little of a public figure to elicit such interest. See, e.g., Georg Winter, “Erinnerungen an Leopold von Ranke," Nord und Süd, 38 (1886), 204-25; Theodor Wiedemann, “Sechzehn Jahre in der Werkstatt Leopold von Ranke's: Ein Beitrag zur Geschichte seiner letzten Lebensjahre," Deutsche Revue, 16/4 (1891), 164-79 (with thirteen subsequent installments); “Aus Heinrich von Sybel’s Heim,” Leipziger Tagesblatt (15 August 1895).

${ }^{26}$ On necrological genres in nineteenth-century Germany, see Ralf Georg Bogner, Der Autor im Nachruf: Formen und Funktionen der literarischen Memorialkultur von der Reformation bis zum Vormärz (Tübingen, 2006), 361-77. On scholarly necrologies more specifically, see Anna Echterhölter, Schattengefechte:
}

Genealogische Praktiken in Nachrufen auf Naturwissenschaftler (1710-1860) (Göttingen, 2012); Hans Kloft, "Die Nachrufe auf Theodor Mommsen," in Alexander Demandt, Andreas Goltz, and Heinrich Schlange-Schöningen, eds., Theodor Mommsen: Wissenschaft und Politik im 19. Jahrhundert (Berlin, 2005), 282-317; Friedrich Wilhelm Graf, “Polymorphes Gedächtnis: Zur Einführung in die Troeltsch-Nekrologie,” in Friedrich Wilhelm Graf with Christian Nees, eds., Ernst Troeltsch in Nachrufen (Gütersloh, 2002), 21-173, esp. 23-5.

${ }^{27}$ Bogner, Autor im Nachruf, 373.

28 “Underrättelser," Historisk Tidskrift, 6 (1886), 185-92, at 189; “Necrologie,” De Nederlandsche Heraut, 3 (1886), 129-32, at 131-2; R[ichard?] Schr[öder?], untitled necrology of Waitz, Zeitschrift der Savigny-Stiftung für Rechtsgeschichte, 8 (1887), 198-9; A. Hagedorn, "Zum Andenken an Georg Waitz," Mittheilungen des Vereins für Lübeckische Geschichte und Alterthumskunde, 2/10 (1886), 145-9; Fr[iedrich] B[ienemann], “Ein 
as a great contributor to German historical studies. ${ }^{29}$ More specialist periodicals, by contrast, sought to determine what was distinctive about Waitz by comparing him to colleagues near and abroad. ${ }^{30}$ It was especially in those pieces, written by and for historians, that authors explicitly weighed Waitz's merits, thereby adopting the subject position of a judge, qualified to "take stock" of the deceased's life and work, as one obituary put it. ${ }^{31}$

Invariably, judgment was phrased in terms of virtue and vice. Although only some obituary writers explicitly referred to Waitz's "virtues" (Tugenden) or "qualities of character" (Eigenschaften des Charakters), all of them invoked dispositions that were conventionally classified as "virtues of the historian" (Tugenden des Geschichtschreibers): "love of truth," "meticulousness down to the smallest details," "an exceptionally critical attitude," "never ceasing diligence," "strict conscientiousness," and "the purest objectivity." ${ }^{32}$ In modern terminology, quite a few of these qualities served as epistemic virtues in the sense that they were seen as features contributing to the pursuit of reliable historical knowledge. Yet in other cases, social and moral layers of meaning were at least as significant. August

Gedenkblatt an Georg Waitz," Baltische Monatsschrift, 33 (1886), 510-12; [Lothar] v[on] Thüna, "Nachruf," Zeitschrift des Vereins für Thüringische Geschichte und Altertumskunde, 5 (1887), unpag.; C. Er. Carstens, “Geheimrath Professor Dr. G. Waitz," Zeitschrift der Gesellschaft für Schleswig-Holstein-Lauenburgische Geschichte, 17 (1887), 366-74.

${ }^{29}$ Friedrich Cauer, "Ranke, Waitz, Duncker: Ihre Stellung in der deutschen Wissenschaft: Ihr Einfluß auf deutsche Bildung: Dem Andenken dreier großer Denker und Lehrer," Die Frau im gemeinnützigen Leben, 2 (1887), 89-96.

${ }^{30}$ E.g., Georges Blondel, Notice sur Georges Waitz (Paris, 1886), 6.

${ }^{31}$ Ludwig Weiland, Georg Waitz (geb. 9. October 1813, gest. 24. Mai 1886): Rede gehalten in der öffentlichen Sitzung der K. Gesellschaft der Wissenschaften am 4. Dezember 1886 (Göttingen, 1886), 3. The independence of these self-appointed judges had its limits. Especially former students borrowed heavily from their deceased teacher, most notably by describing him in terms of "loyalty" (Treue) - a key virtue in the idealized portrayal of Germanic morality that Waitz had provided in his Deutsche Verfassungsgeschichte, vol. 1, 3rd ed. (Kiel, 1880), 46-7. As illustrated by K. Jansen, "Ein Gedenkblatt für Georg Waitz," Kieler Zeitung (19 and 20 April 1887), independency of judgment was also limited by sometimes dense layers of intertextuality.

${ }^{32}$ [Wilhelm] v[on] B[ippen], “Georg Waitz,” Weser Zeitung (30 May 1886); “Bericht über die zwölfte Plenarversammlung," 4, 5; G. Monod, “Georges Waitz," Revue historique, 31 (1886), 382-90, at 390; [Hubert Ermisch], “Georg Waitz + 24. Mai 1886," Wissenschaftliche Beilage der Leipziger Zeitung (1886), 265-9, at 268; Alfred Stern, “Georg Waitz," Die Nation, 3 (1886), 538-40, at 538; idem, “Gedächtnisrede auf Leopold von Ranke und Georg Waitz," Jahrbuch für schweizerische Geschichte, 12 (1887), xi-xxxvi, at xxx, xxxii; Hagedorn, “Andenken," 146. 
Kluckhohn, for instance, honored an inspiring teacher and faithful friend as much as a courageous scholar when he called Waitz "a man of rare candor [Geradheit], loyalty, and goodness." "33 "Loyalty," specifically, was a virtue associated with all sorts of pursuits: it was said to characterize Waitz as a researcher, teacher, politician, husband, father, and friend. ${ }^{34}$ Virtues therefore had a scope beyond the epistemic: they referred to character traits that could be appreciated for social, moral, or political reasons, too. ${ }^{35}$

If Waitz was found guilty of vices, these were typically perceived as virtues run wild that is, in classical Aristotelian manner, as virtues turned into vices through exaggeration or lack of balance. Wilhelm Wattenbach, for instance, told the Berlin Academy of Sciences that Waitz's aversion to "combination" had gone too far and that especially his students had focused their attention "too strongly and one-sidedly" on issues of source criticism. ${ }^{36}$ This echoed Heinrich von Sybel's obituary of Waitz in the Kölnische Zeitung, which will be discussed below, as well as a necrology in the Vossische Zeitung that had accused Waitz of having "frittered away his talent" by getting bogged down in a "gigantic work for which historical research at the time was not ripe and that by its very nature could not find a large readership" (a reference to Waitz's Deutsche Verfassungsgeschichte, which had appeared in eight volumes between 1844 and 1878). Although the anonymous author of this necrology had added that few historians surpassed Waitz in "diligence" and "astuteness" (Scharfsinn), he had left no doubt that these virtues alone did not make a good historian. ${ }^{37}$

\footnotetext{
${ }^{33}$ A[ugust] K[luckhohn], “Georg Waitz," Allgemeine Zeitung (1886), 4017-18, 4041-2, 4313-14, 4385-6, at 4017.

${ }^{34}$ [Ermisch], "Georg Waitz," 269; [Wilhelm] Wattenbach, "Gedächtnisrede auf Georg Waitz," in Abhandlungen der Königlichen Akademie der Wissenschaften zu Berlin aus dem Jahre 1886 (Berlin, 1887), 1-12, at 3. On the social and political connotations of "loyalty" in this period, see Nikolaus Buschmann, "Die Erfindung der deutsche Treue: Von der semantischen Innovation zur Gefolgschaftsideologie," in Nikolaus Buschmann and Karl Borromäus Murr, eds., Treue: Politische Loyalität und militärische Gefolgschaft in der Moderne (Göttingen, 2008), 75-109.

${ }^{35}$ As emphasized by Camille Creyghton et al., "Virtue Language in Historical Scholarship: The Cases of Georg Waitz, Gabriel Monod and Henri Pirenne," History of European Ideas, 42 (2016), 924-36. On the moral and political subtexts of virtue language in scholarly obituaries, see Dorinda Outram, "The Language of Natural Power: The 'Eloges' of Georges Cuvier and the Public Language of Nineteenth Century Science," History of Science, 16 (1978), 153-78; Charles B. Paul, Science and Immortality: The Éloges of the Paris Academy of Sciences (1699-1791) (Berkeley, CA, 1980).

${ }^{36}$ Wattenbach, “Gedächtnisrede," 8, 9.

37 “Georg Waitz †," Vossische Zeitung (25 May 1886).
} 
Given the genre's tendency towards intertextual commentary, it comes as no surprise that other obituary writers openly disagreed. Complaining "that the contemptuous manner in which [Waitz's] achievements have been judged in the press in the past few days is founded merely on ignorance or lack of understanding for them," Hubert Ermisch argued that it was no fault on Waitz's part that he had never written books of the sort that had secured Droysen's and Sybel's reputations: Waitz had been able to resist the vice of seeking fame. ${ }^{38}$ Similarly, in the best tradition of "research" (Forschung) conceived of as "work" (Arbeit), Kluckhohn argued that it was the privilege of only a few to devote themselves to Darstellung:

Only few are called to engage in profound, ground-breaking research or even to create historiographical works of art with lasting value. For a master of scholarship, it is fame enough to be told by the world that he has trained useful and reliable disciples, faithful to their duty and impassioned for their vocation, in such a considerable number as G. Waitz has succeeded in doing. ${ }^{39}$

The question running throughout the obituaries was therefore not whether Waitz had been a virtuous historian, but which virtues he had displayed and to what extent. More precisely, the question for Waitz's obituary writers was how much weight he had attached to various virtues and how this had earned him a profile that distinguished him, positively or negatively, from other historians. Accordingly, when Waitz's obituary writers took sides with or against each other, the issue at stake was to what extent and in what way Waitz could serve as a model of virtue, compared to others committed to different virtue catalogs. Was Waitz's dedication to "criticism," "precision," and "penetration" an example to be imitated or a model in need of revision?

\footnotetext{
38 [Ermisch], “Georg Waitz," 268. For Ermisch's subsequent attempts to manage Waitz's posthumous reputation, see Hubert Ermisch, Zur Erinnerung an Georg Waitz (Dresden, 1913); Ferdinand Frensdorff, "Zur Erinnerung an den 25. Oktober 1913," Hansische Geschichtsblätter, 41 (1914), 291-9, at 294; “Waitz-Feier,” Historische Vierteljahrschrift, 17 (1914-15), 150-1.

${ }^{39}$ K[luckhohn], "Georg Waitz," 4042. On Forschung as Arbeit, see Schnicke, Männliche Disziplin, 251-341; Wolfgang Hardtwig, "Geschichtsreligion, Wissenschaft als Arbeit, Objektivität: Der Historismus in neuer Sicht," Historische Zeitschrift, 252 (1991), 1-32, at 19-32.
} 
In order to understand why Waitz was transformed into a model of virtue and why this model in turn was consistently compared to alternative models, the next two sections will zoom in on two obituary writers: Ludwig Weiland and Hermann Grauert. Both were former students of Waitz who used their necrologies to position themselves vis-à-vis a number of competing models of how to be a good historian in 1880s Germany. A close look at these attempts at historiographical "map making" will prepare the way for a more general answer as to why commemoration of Waitz's virtues mattered to historians divided along professional, political, and religious lines.

\section{Criticism vs. combination}

Weiland's obituary, to begin with, started as a lecture to the Göttingen Academy of Sciences. The choice for Ludwig Weiland as a commemorative speaker was unsurprising: the man held Waitz's former chair and was known as "a truly extraordinary influential member" of the Academy. ${ }^{40}$ Importantly, Weiland also mastered the art of speech, judging by some earlier, well-received addresses, and could be regarded as deeply congenial to his former teacher. ${ }^{41}$ A specialist in medieval history, Weiland showed himself committed to the very same virtues that Waitz had tried to instill in his students. ${ }^{42}$ Notably, in a classic instance of nineteenthcentury "suffering for science," he spent almost his entire working life editing sources for the Monumenta Germaniae Historica, despite an eye defect that limited his reading ability. ${ }^{43}$

\footnotetext{
${ }^{40}$ Ulrich von Wilamowitz-Moellendorff to Theodor Mommsen, 30 March 1887, in William M. Calder III and Robert Kirstein, eds., "Aus dem Freund ein Sohn": Theodor Mommsen und Ulrich von Wilamowitz-Moellendorff: Briefwechsel 1872-1903, vol. 2 (Hildesheim, 2003), 409-10, at 410.

${ }^{41}$ Ludwig Weiland, “Zum Andenken an Reinhold Pauli: Vortrag gehalten auf der Versammlung zu Kiel,” Hansische Geschichtsblätter, 12 (1883), 1-9; idem, Friedrich Christoph Dahlmann: Rede zur Feier seines hundertjährigen Geburtstages am 13. Mai 1885 im Namen der Georg-Augusts-Universität gehalten (Göttingen, 1885); Max Lehmann, "Gedächtnisrede auf Ludwig Weiland," in Nachrichten von der Königl. Gesellschaft der Wissenschaften zu Göttingen (1895), 78-80, at 79-80.

${ }^{42}$ Eckhard Müller-Mertens, “Constitutiones et acta publica: Paradigmenwechsel und Gestaltungsfragen einer Monumenta-Reihe," in Michael Lindner, Eckhard Müller-Mertens, and Olaf B. Rader, eds., Kaiser, Reich und Region: Studien und Texte aus der Arbeit an den Constitutiones des 14. Jahrhunderts und zur Geschichte der Monumenta Germaniae Historica (Berlin, 1997), 1-59, at 24.

${ }^{43}$ Jakob Schwalm, Gedächtnisworte für Ludwig Weiland gesprochen bei der Trauerfeier des AkademischHistorischen Vereins am 28. Februar 1895 (Göttingen, 1895), 10.
} 
Yet whatever expectations Weiland might have raised, his lecture was not uncritical of Waitz. Although his prose was weighted with admiration for Waitz's "character pure as gold," Weiland noted that Waitz's "objectivity" had had the effect of suppressing his talent for "combination." 44 Among nineteenth-century historians, Combinationsgabe referred to a talent for conjecture indispensable for any scholar whose ambitions reached beyond collection of data. In his Lehrbuch der historischen Methode (1889), Ernst Bernheim characterized it as the ability to connect dots or to recognize patterns in a set of data. ${ }^{45}$ Under reference to other German authors, a British scholar, writing in the 1890s, described it more eloquently as "the faculty of detecting affinities between seemingly unrelated facts, and bringing out their real significance by the unexpected light which they are made to throw upon each other." 46

What made "combination" so defined a delicate aspect of historical studies was its affinity with "phantasy" - a faculty that historians generally considered as contrary to the demands of serious, fact-based scholarship. ${ }^{47}$ Although Weiland was convinced that "history conceived of as art cannot do without" it, he argued that Waitz had been so suspicious of everything resembling phantasy that he had deliberately "bridled the inclination towards combination" and sacrificed all speculative inference for the good of solid, reliable, factual knowledge. ${ }^{48}$ This had become most apparent in Waitz's controversies with "prominent scholars, lawyers and historians" - a veiled reference to especially Paul Roth, a leading German historian of law - whom Weiland described as considerably less afraid of the "dazzling gift of combination." ${ }^{49}$ In the 1850s and 1860s, Waitz and Roth had crossed swords over the origins of Merovingian feudalism, whereby the former had repeatedly reproached

\footnotetext{
${ }^{44}$ Weiland, Georg Waitz, 14, 7.

${ }^{45}$ Ernst Bernheim, Lehrbuch der historischen Methode: Mit Nachweis der wichtigsten Quellen und Hülfsmittel zum Studium der Geschichte (Leipzig, 1889), 429. Similarly: Heinrich Finke, “† Adolf Tibus,” Zeitschrift für vaterländische Geschichte und Alterthumskunde, 53 (1895), 327-42, at 334.

${ }^{46}$ J. Skinner, review of Carl Niebuhr, Geschichte des Ebräischen Zeitalters, vol. 1, The Critical Review, 5 (1895), 170-4, at 173.

${ }^{47}$ Bernheim, Lehrbuch der historischen Methode, 431.

${ }^{48}$ Weiland, Georg Waitz, 6.

${ }^{49}$ Ibid., 10.
} 
the latter for his "arbitrary" explanations, "unfounded" assumptions, and "uncertain combinations." 50

Although Weiland to some extent appreciated this suspicion of "combination of facts," he believed that Waitz's strength had been a weakness, too. ${ }^{51}$ The price Waitz had to pay for his matter-of-factness was a renunciation of any attempt to uncover patterns of development and of providing readers with a "lively, vivid image" of the past. ${ }^{52}$ Additionally, Weiland complained that Waitz had socialized an entire generation of historians into an ethos privileging "criticism" over "combination." If all those men followed Waitz in regarding criticism as the nec plus ultra of historical scholarship, who would be left to propose a bold hypothesis or write a wide-ranging book?

If I am not mistaken, the persuasion [Richtung] in historical scholarship of which Georg Waitz was the main representative has been elevated for a while too much above other persuasions. It was not he who bore guild for this overrating. It was far from him to claim "that only one path is correct and that scholarship can be served only in one way." But the sheer number of his students, all of whom confessed that they owed much or everything to the master, seemed to give a loud and widely resounding testimony to the supremacy of the persuasion that Waitz represented. ${ }^{53}$

In a characteristic move, Weiland continued that such self-complacency had been counterproductive in generating its own opposing forces, some of which now seemed eager to relegate the entire Waitzian tradition to the past. ${ }^{54}$ Remarkable about this argument is

\footnotetext{
${ }^{50}$ Georg Waitz, Über die Anfänge der Vassallität (Göttingen, 1856), 69, 75; G. Waitz, “Die Anfänge des Lehnwesens," Historische Zeitschrift, 13 (1865), 90-111, at 105. At other occasions, too, Waitz had warned that reliability is often the first victim of overhasty combination: Georg Waitz, "Falsche Richtungen: Schreiben an den Herausgeber," Historische Zeitschrift, 1 (1859), 17-28, at 24-5. For the specific connotations of "combination" among mid-nineteenth-century German lawyers and historians of law, see Sten Gagnér, "Zielsetzungen und Werkgestaltung in Paul Roths Wissenschaft," in Sten Gagnér, Hans Schlosser, and Wolfgang Wiegand, eds., Festschrift für Hermann Krause (Cologne, 1975), 276-450, at 294-301.

${ }^{51}$ Weiland, Georg Waitz, 11.

52 Ibid., 10-11.

${ }^{53}$ Ibid., 4, quoting from Waitz, "Falsche Richtungen," 19.

${ }^{54}$ Weiland, Georg Waitz, 4.
} 
that it implied the subject position of an outsider, who could refer to Waitz's students in the third person plural ("they"). Weiland presented himself as an independent observer, qualified to evaluate the strengths and weaknesses of Waitz-style Forschung in comparison to other, competing approaches to historical scholarship.

In adopting this position as well as in criticizing Waitz's suspicion of Combinationsgabe, Weiland followed no one other than Sybel, Germany's most influential critic of Waitz-style historiography (friendly relations between Sybel and Waitz themselves notwithstanding). ${ }^{55} \mathrm{~A}$ couple of months before Weiland delivered his lecture, Sybel had commemorated his former fellow-student with a necrology in the Kölnische Zeitung that had wrapped serious criticism in lavish praise. Although Sybel had acknowledged that Waitz's knowledge and precision had been unsurpassed, he had added that this strength had been a weakness, too. By devoting all his energy to specialist research, Waitz had neglected two other, equally important tasks of the historian: interpretation (especially of political states of affairs) and writing (for academic and non-academic audiences alike). For Sybel, then, an historian had to be a researcher, but also a "political expert," capable of understanding the political intricacies of times past, and an "artist," gifted with sufficient Combinationsgabe to bring the past to life in narrative form. By foregoing all "construction," "summary," and "inference" (Schlußfolgerung), Waitz had proved himself as rather one-sided - to which Sybel had added politely that one-sidedness is not seldom a key to success. ${ }^{56}$

How was it possible that one of Waitz's closest students took sides with Sybel, whose description of himself as "four-seventh professor and three-seventh politician" sufficed to illustrate his distance from Waitz ${ }^{57}$ The question deepened itself over the course of the next

\footnotetext{
${ }^{55}$ As Bernheim observed in 1885: "[Waitz] has only made the easily forgivable but counterproductive mistake of favoring especially those who pair unconditional and oft-proclaimed personal devotion to spiritual dependency. I am afraid the response will go far beyond its goal and lead for a while to antithetical aversion. The Sybelian 'kat exochen' will thereby play the role of the Girondins." Ernst Bernheim to Karl Lamprecht, 2 January 1885, in Luise Schorn-Schütte and Mircea Ogrin, eds., "Über das eigentliche Arbeitsgebiet der Geschichte": Der Briefwechsel zwischen Karl Lamprecht und Ernst Bernheim sowie zwischen Karl Lamprecht und Henri Pirenne 1878-1915 (Cologne, 2017), 67.

${ }^{56}$ Heinrich v[on] Sybel, “Georg Waitz," Kölnische Zeitung (26 May 1886), reprinted in Sybel's Historische Zeitschrift, 56 (1886), 482-7.

${ }^{57}$ Heinrich von Sybel to Johann Caspar Bluntschli, date unknown, as quoted in Conrad Varrentrapp,

"Biographische Einleitung," in Heinrich von Sybel, Vorträge und Abhandlungen, ed. Conrad Varrentrapp
} 
year and a half, when Weiland made two other surprising moves. One was a spirited defense of Waitz's source-critical attitude against Ottokar Lorenz, the German-Austrian historian who right after Waitz's death had issued a strong complaint about the editorial policies of the Monumenta. ${ }^{58}$ Weiland so passionately defended the series and the principles on which it rested that Ulrich von Wilamowitz-Moellendorff, the classical philologist from Göttingen, read it as a veiled application to the presidential position that Waitz's death had left vacant. ${ }^{59} \mathrm{~A}$ second surprise, then, came in 1888 , when Weiland was offered the prestigious post and declined it. A puzzled Wilamowitz wrote his father-in-law, Theodor Mommsen, that he could not believe Weiland's excuse (the delicate health of his wife): "[T]here must be a hidden motive." ${ }^{60}$ So what was the rationale behind Weiland's maneuvering?

Arguably, both Weiland's ambiguity about Waitz's lack of Combinationsgabe and his defense of Waitz against Lorenz stemmed from an ambivalence that Weiland had come to feel about the editorial work to which he had devoted the better part of his career. Although he was sufficiently convinced of the need for critical source editions to sacrifice many of his own research ambitions to the Monumenta, he increasingly hoped to find time for writing a more substantial narrative piece of work - a history of medieval German law or a biography of King Ludwig of Bavaria. ${ }^{61}$ While dutifully continuing work on the first and second volumes of the Constitutiones et acta publica imperatorum et regum $(1893,1896)$, he enthusiastically told his friends that the Herculean task was almost completed. ${ }^{62}$ Those who had heard him

(Munich, 1897), 1-156, at 128; Thomas Brechenmacher, “Wie viel Gegenwart verträgt historisches Urteilen? Die Kontroverse zwischen Heinrich von Sybel und Julius Ficker über die Bewertung der Kaiserpolitik des Mittelalters (1859-1862)," in Jürgen Elvert and Susanne Krauß, eds., Historische Debatten und Kontroversen im 19. und 20. Jahrhundert (Stuttgart, 2003), 34-54, at 53.

${ }^{58}$ Ludwig Weiland, “Quellenedition und Schriftstellerkritik," Historische Zeitschrift, 58 (1887), 310-35, at 335, in response to Ottokar Lorenz, Deutschlands Geschichtsquellen im Mittelalter seit der Mitte des dreizehnten Jahrhunderts, vol. 2, 3rd ed. (Berlin, 1887), iii-xii.

${ }^{59}$ Ulrich von Wilamowitz-Moellendorff to Theodor Mommsen, 27 February 1888, in Calder and Kirstein, Aus dem Freund ein Sohn, vol. 2, 461-2.

60 Ibid.

${ }^{61}$ P[aul] H[asse], “Professor Dr. Ludwig Weiland †," Lübeckische Blätter, 37 (1895), 61-2, at 62; “Vermischtes," Historische Zeitschrift, 74 (1895), 564-8, at 568.

${ }^{62}$ Ferdinand Frensdorff, "Zur Erinnerung an Ludwig Weiland: Vortrag auf der Versammlung des Hansischen Geschichtsvereins zu Bielefeld am 4. Juni 1895," Hansische Geschichtsblätter, 22 (1894), 107-26, at 117-18. 
commemorate Reinhold Pauli (1883) and Dahlmann (1885) had caught a glimpse of what Weiland was looking for. He had praised Pauli for his talent for drawing a "colorful culturalhistorical image" on the base of scattered pieces of information - a talent requiring "gift of combination." Likewise, he had commended Dahlmann's history of Denmark for its "vividness" (Anschaulichkeit) and "power of depiction" (Kraft der Darstellung). ${ }^{63}$ A couple of years later, he would also speak highly about John Lothrop Motley's "lively" and "captivating" style of writing. ${ }^{64}$ Clearly, Weiland sought and found inspiration in historians less cautious than Waitz in employing "combination." This may well explain why Weiland's refused to succeed Waitz as president of the Monumenta: he dreamed of devoting himself to similar tasks. ${ }^{65}$

Weiland, in sum, used the occasion of Waitz's death to draw an imaginary map of the historical discipline, to position his former teacher on it - at the utmost right side in so far as Combinationsgabe was concerned - and to inscribe himself in a tradition of skepticism towards exclusive emphasis on philological virtues. ${ }^{66}$ For Weiland, comparing himself to Waitz and Waitz to Dahlmann, Pauli, and Motley was a way of determining where in the divided world of German historiography he belonged in terms of vocational aspirations.

\section{Ranke vs. Janssen}

\footnotetext{
${ }^{63}$ Weiland, "Zum Andenken," 5; Weiland, Friedrich Christoph Dahlmann, 6.

64 “Rede des Herrn Prof. Dr. Weiland," in Fest-Reden bei der Erinnerungs-Feier an Edward Everett, George Bancroft, Henry W. Longfellow und John L. Motley gehalten in der Aula der Georgia-Augusta, Göttingen, 4. Juli 1890 (Göttingen, [1890]), 14-19, at 17.

${ }^{65}$ Frensdorff, "Zur Erinnerung," 117; Harry Bresslau, Geschichte der Monumenta Germaniae Historica (Hanover, 1921), 634.

${ }^{66}$ The metaphor of left and right-wing positions comes from Sigmund Riezler, Gedächtnisrede auf Wilhelm von Giesebrecht gehalten in der öffentlichen Sitzung der k. b. Akademie der Wissenschaften zu München zur Vorfeier ihres 132. Stiftungstages am 21. März 1891 (Munich, 1891), 14. Johann Gustav Droysen and Jacob Burckhardt were among those repeatedly warning against overemphasis on philological virtues: Johann Gustav Droysen to Max Duncker, 24 February 1845, in Droysen, Briefwechsel, ed. Rudolf Hübner, vol. 1 (Osnabrück, 1929), 307-9; Jacob Burckhardt to Gottfried Kinkel, 17 April 1847, in Burckhardt, Briefe, ed. Max Burckhardt, vol. 3 (Basel., 1955), 65-8; Burckhardt to Wilhelm Visscher, Jr., 20 June 1859, in Burckhardt, Briefe, ed. Max Burckhardt, vol. 4 (Basel, 1961), 39-41.
} 
Similar attempts at "map making" were made by Catholic historians, among whom Waitz did not enjoy a particularly good reputation. ${ }^{67}$ As late as 1875 , the young Catholic historian Ludwig Pastor had described Waitz as a "Prussian monopolist of history" - a phrase echoing earlier Catholic descriptions of Sybel and Giesebrecht. ${ }^{68}$ Pastor identified with Johannes Janssen, a man who had pitted himself in opposition to Ranke and his pupils by committing himself to an apologetically framed Catholic interpretation of the German past. ${ }^{69}$ This was atypical for Pastor's generation, though, as many Catholic students born around mid-century searched for less antithetical approaches to "modern" historical studies or even for reconciliation between Catholic faith and "critical" scholarship. As such, they anticipated the even larger groups of Catholics in late nineteenth-century Germany that went to university in order to remedy their perceived "educational deficit" (Bildungsdefizit). ${ }^{70}$

This explains why Hermann Grauert and various other Catholic students - Florenz Tourtual, August von Druffel, Hermann Cardauns, and Georg Hüffer - went to Göttingen, Waitz's anti-Catholic reputation notwithstanding, to study with the man whose learning, in Cardaun's words, had a magnetic effect on every aspiring historian in Germany. ${ }^{71}$ Around

\footnotetext{
${ }^{67}$ See, e.g., Johann Friedrich Böhmer to Joseph Eutych Kopp, 6 September 1846, in Joh. Friedrich Böhmer's Briefe, ed. Johannes Janssen, vol. 1 (Freiburg, 1868), 451, in response to Waitz's warnings against "ultramontanism" in "Deutsche Historiker der Gegenwart: Briefe an der Herausgeber," Allgemeine Zeitschrift für Geschichte, 5 (1846), 520-35.

${ }^{68}$ [Ludwig] P[astor], “Georg Waitz als preußischer Geschichtsmonopolist,” Der Katholik, 55 (1875), 435-45; [Joseph Edmund Jörg?], "Ein Programm der historischen Sekte des Herrn von Sybel," Historisch-politische Blätter für das katholische Deutschland (1858), 400-8; Giesebrecht's Geschichtsmonopol im paritätischen Bayern (Mainz, 1865).

${ }^{69}$ Johannes Wischmeyer, “Objektivitätsideal zwischen Toleranz und Revisionismus: Leopold von Ranke und Ludwig von Pastor als Historiographen des Papsttums," in Kerstin Armborst-Weihs and Judith Becker, eds., Toleranz und Identität: Geschichtsschreibung und Geschichtsbewusstsein zwischen religiösem Anspruch und historischer Erfahrung (Göttingen, 2010), 253-72; Andreas Holzem, Weltversuchung und Heilsgewißheit: Kirchengeschichte im Katholizismus des 19. Jahrhunderts (Altenberge, 1995), 180-94; Walter Troxler, Ein Aussenseiter der Geschichtsschreibung: Johannes Janssen 1829-1891: Studien zu Leben und Werk eines katholischen Historikers (Berlin, 2007).

${ }^{70}$ Christoph Dowe, Auch Bildungsbürger: Katholische Studierende und Akademiker im Kaiserreich (Göttingen, 2006).

${ }^{71}$ Hermann Cardauns, Aus dem Leben eines deutschen Redakteurs (Cologne, 1912), 48; Bernd Mütter, Die Geschichtswissenschaft in Münster zwischen Aufklärung und Historismus unter besonderer Berücksichtigung der
} 
1880, these Catholic students grouped themselves around the Historisches Jahrbuch published by the Görres Society - a journal that was simultaneously intended as a Catholic alternative to Sybel's Historische Zeitschrift (from which Catholic authors were excluded) and as a scholarly alternative to the Historisch-politischen Blätter für das katholische Deutschland (a conservative Catholic periodical). From the very beginning, this twofold ambition had met with suspicion, especially among more traditionally inclined Catholics. ${ }^{72}$ Not long after Grauert had taken over editorship of the Historisches Jahrbuch in 1885, Pastor, for instance, criticized the editor for an inclination towards compromise, which he perceived as neither fish nor fowl and hence as neither advantageous to the Catholic cause nor convincing to Protestant "adversaries."

Against this background, Grauert's lengthy necrology of Waitz - the article spanned 53 pages - came close to a manifesto, for no less than four reasons. Grauert hit a sensitive chord, first, by applauding the "really critical philological method" or "method of exact, critical historical research" in which he and other students of Waitz had been trained. ${ }^{74}$ In a milieu in which the pros and cons of this critical method were an issue of debate, especially if applied to saints' lives and miracle stories, this was a controversial thing to do. ${ }^{75}$ Even more controversial was Grauert's portrayal of Waitz as an embodiment of "objectivity" - a word he used as synonymous to "impartiality." "76 "Objectivity," Grauert declared, "is the goal on which every scholarly historian should set their eyes":

historischen Disziplin an der Münsterschen Hochschule (Munster, 1980), 246, 247; Bernd Mütter, “Georg Hüffer (1851-1922): Ein katholischer Historiker zwischen Kirche und Staat, Ultramontanismus und Historismus," Westfälische Forschungen, 61 (2011) 307-43, at 308-10.

${ }^{72}$ Mütter, Geschichtswissenschaft in Münster, 248.

${ }^{73}$ Ludwig Freiherr von Pastor, Tagebücher, Briefe, Erinnerungen, ed. Wilhelm Wühr (Heidelberg, 1950), 270, 288.

${ }^{74}$ Herm[ann] Grauert, “Georg Waitz," Historisches Jahrbuch, 8 (1887), 48-100, at 55, 99.

${ }^{75}$ See, e.g., the controversy that arose over the first volume of Georg Hüffer's biography of Bernard of Clairvaux (1886): [August] v[on] Druffel, review in Göttingische Gelehrte Anzeigen (1888), 1-20; G. Hüffer, "In eigener Sache: Antwort an A. v. Druffel," Historisches Jahrbuch, 9 (1888), 480-90; G. Hüffer, “Die Wunder des hl. Bernhard und ihr Kritiker," Historisches Jahrbuch, 10 (1889), 23-46, 748-806.

${ }^{76}$ On the complex relation between "impartiality" and "objectivity" in nineteenth-century historiography, see Lorraine Daston, “Objectivity and Impartiality: Epistemic Virtues in the Humanities," in Rens Bod, Jaap Maat, and Thijs Weststeijn, eds., The Making of the Humanities, vol. 3 (Amsterdam, 2014), 27-41, esp. 31. 
What really matters is to explain and to judge people, facts, and situations of the past from the conditions around them, out of which they have emerged. To no small degree, the mastery of Ranke's historical writing consists herein that he suppresses his subjective personal judgment as far as possible and seeks to understand the people and the occurrences that he deals with from their own time. ${ }^{77}$

Although objectivity in this sense of "suppressing personal judgment" was quickly winning ground among Catholic historians, by the 1880 s it was still unusual to present Ranke and Waitz as paragons of this virtue. This amounted, after all, to critical dissociation from the time-honored view that Protestants were blinded by partiality and, consequently, unable to see the salutary influence of the Church throughout history or the scholarly achievements of Catholic historians. On this ground, Pastor had accused both Ranke and Waitz of "unbelievable partiality." ${ }^{\prime 78}$ Grauert thus broke with a Catholic tradition by hailing Ranke and Waitz as models of objectivity.

From this it followed, in the third place, that Grauert had to attenuate Waitz's antiCatholicism. While Pastor had denounced Waitz's "hate of Catholics," ${ }^{179}$ Grauert countered that Waitz's objectivity had been strong enough to appreciate the merits of non-Protestant authors. Drawing on his own experience, he recounted that Catholic students in Göttingen had always enjoyed Waitz's counsel and friendly encouragement. ${ }^{80}$ Although he consented that older texts of Waitz showed evidence of unfortunate anti-Catholicism, especially in employing pejorative terms like "ultramontanism," ${ }^{81}$ Grauert did not take this to imply that Waitz had considered Catholic historiography a contradiction in terms. Significantly, he added that Waitz "had said many true things about dilettantism, false conservatism, wrong

\footnotetext{
${ }^{77}$ Grauert, "Georg Waitz," 94.

78 Pastor, Tagebücher, 88; P[astor], “Georg Waitz," 439.

${ }^{79}$ P[astor], “Georg Waitz," 445. See also Pastor, Tagebücher, 104.

${ }^{80}$ Grauert, “Georg Waitz," 99.

${ }^{81}$ For the connotations of this term, see Heribert Raab, "Zur Geschichte und Bedeutung des Schlagwortes

'Ultramontan' im 18. und frühen 19. Jahrhundert," Historisches Jahrbuch, 81 (1961), 159-73.
} 
feigned learning, and arbitrary yearning for combination [Kombinationssucht] in historical research" - a remark that Pastor could take to heart. ${ }^{82}$

Finally, Grauert argued that Waitz deserved gratitude because of the solid training he had offered to Catholic students. "[Historians] from our circle, too, gladly joined other students in expressing continuing reverence and gratitude to the teacher at special occasions." $^{83}$ This shifted the discussion from an epistemic to a social level. Grauert positioned himself within a network of former students of Waitz and, consequently, within a group of scholars of whom only a small minority belonged to the Roman Catholic Church. Unlike Pastor, who mentioned the coursework he had done with Waitz only if necessary for demonstrating professional competence, Grauert considered it a privilege to have studied with the man - the "leader [Führer], teacher, and master," as he would later call him - who had taught him "to suppress his subjective personal judgment as far as possible." ${ }^{84}$

In sum, while Grauert's necrology resembled other, non-Catholic obituaries in pairing gratitude to the deceased with defense against critics, in the context of the Görres Society, Grauert's panegyric on Waiz's objectivity amounted to critical dissociation from those identifying with Janssen's apologetic tradition. This did not imply that Grauert, confronted with a choice between "Janssen" and "Ranke," always opted for the latter. Only a year before, in the Historisches Jahrbuch, he had added an editorial footnote to a Ranke article by Alfred von Reumont, in which Grauert had dissociated himself from what he had perceived as a too rose-colored portrayal of Ranke's piousness. ${ }^{85}$ Grauert is therefore best understood as someone navigating between the traditions embodied by Ranke and Waitz on the one hand and Janssen and Pastor on the other. The Waitz necrology was Grauert's means for articulating and justifying his position vis-à-vis both traditions.

\footnotetext{
${ }^{82}$ Grauert, "Georg Waitz," 95.

${ }^{83}$ Ibid., 99-100. Grauert had participated in the 1874 commemoration of Waitz's historische Übungen ([Höhlbaum], Jubelfeier, 19). His name had also appeared on Die zum 9. October an G. Waitz nach Bellagio am Comer See übersandte Adresse (Berlin, 1883).

${ }^{84}$ Ludwig Pastor to Franz Xaver Kraus, 25 January 1890, in Hubert Schiel, “Ludwig von Pastors Briefwechsel mit Franz Xaver Kraus," Rheinische Vierteljahrsblätter, 19 (1954), 191-233, at 204; Hermann Grauert, untitled autobiography, in W. Zils, ed., Geistes und künstlerisches München in Selbstbiografien (Munich, 1913), 117-25, at 121 .

${ }^{85}$ A. v[on] Reumont, “Leopold von Ranke,” Historisches Jahrbuch, 7 (1886), 608-35, at 630.
} 
As such, the piece was not particularly appreciated by readers who already had their worries about the direction of the Historisches Jahrbuch. After von Reumont's Ranke article and another remarkably positive piece on the Protestant historian in the pages of the Historisches Jahrbuch, ${ }^{86}$ Grauert's Waitz necrology became the straw that broke the camel's back. At the annual meeting of the Görres Society in October 1887, critics called the editor to account. Although the official report merely speaks about "wishes" and "proposals" that occasioned a "discussion" about the yearbook, editorial assistant Gustav Schnürer provided a more insightful account in reporting that the exchange focused on what was perceived as uncritical approval of Ranke, "the most dangerous enemy of the Cath[olic] church," in the pages of the Historisches Jahrbuch. ${ }^{87}$ Schnürer added that "the audience was obviously biased in favor of the hero of Catholic historical research [Johannes Janssen] and stood on his side." ${ }^{88}$ Grauert's defense of Waitz's objectivity thus launched another round of debate over the relation between Ranke and Janssen. Although Grauert survived the attack, partly because he was backed by the Society's president, Georg von Hertling, his relations with Pastor quickly deteriorated, even to the extent that Pastor at some point decided to break with the Historisches Jahrbuch. ${ }^{89}$

For all parties involved, then, "Janssen," "Ranke," and "Waitz" served as coordinates in relation to which historiographical aspirations could be mapped. Their names were not just proper names, but also served as shorthand for virtue catalogs on which Catholic

\footnotetext{
${ }^{86}$ Victor Gramich, “L. v. Ranke's Weltgeschichte," Historisches Jahrbuch, 5 (1884), 3-51.

${ }^{87}$ Jahresbericht der Görres-Gesellschaft zur Pflege der Wissenschaft im katholischen Deutschland für das Jahr 1887 (Cologne, 1888), 8; Gustav Schnürer to Heinrich Schrörs, 1 February 1888, as quoted in Gregor Klapczynski, Katholischer Historismus? Zum historischen Denken in der deutschsprachigen Kirchengeschichte um 1900: Heinrich Schrörs, Albert Ehrhard, Joseph Schnitzer (Stuttgart, 2013), 22-3 n. 58. On German Catholic attitudes towards Ranke in this period, see Thomas Brechenmacher, Großdeutsche Geschichtsschreibung im neunzehnten Jahrhundert: Die erste Generation (1830-48) (Berlin, 1996), 460-75; Ulrich Muhlack, “Die wissenschaftsgeschichtliche Bedeutung des Indexverfahrens gegen Rankes Papstgeschichte," in Hubert Wolf, Dominik Burkard, and Ulrich Muhlack, Rankes "Päpste" auf dem Index: Dogma und Historie im Widerstreit (Paderborn, 2003), 169-201, at 189-201.

${ }^{88}$ Schnürer to Schrörs, 1 February 1888, as quoted in Klapczynski, Katholischer Historismus, 22-3 n. 58.

${ }^{89}$ W. Baum, “Emil Michael (1852-1917): Persönlichkeit, Leben und Werk," Zeitschrift für katholische Theologie, 93 (1971), 182-99, at 194-7; Christoph Weber, Der "Fall Spahn" (1901): Ein Beitrag zur Wissenschafts- und Kulturdiskussion im ausgehenden 19. Jahrhundert (Rome, 1980), 74-82.
} 
historians of Grauert's generation found it particularly difficult to agree. Grauert's necrology was therefore not just a personal declaration of adherence to Waitz-style historical study, but also an intervention in a delicate debate on where Catholic historians were supposed to stand on the spectrum between "Ranke" and "Janssen."

\section{Scholarly personae}

Comparison, then, between competing models of virtue lay at the heart of the necrological genre, not only for Weiland and Grauert, but for many of Waitz's obituary writers. Compared to Ranke, Waitz had been more "critical," but less "gifted with the art of writing easily," Kluckhohn and one of his colleagues asserted. ${ }^{91}$ "In marked contrast to Ranke," judged another obituary writer, "Waitz had not received the gift of picking out the essential from a mass of material and using it for a clearly outlined narrative." ${ }^{92}$ Referring to Dahlmann, whose name represented a mildly patriotic form of history writing, Ferdinand Frensdorff maintained that "our deceased teacher and friend stands in between Ranke and Dahlmann and reaches a hand to both." ${ }^{13}$ Adding yet another name to the comparison, Wilhelm von Giesebrecht told the Bavarian Academy of Sciences that "in his talent, conditions of life, and way of thinking, Waitz stood closer to [Georg Heinrich] Pertz and Dahlmann than to

\footnotetext{
${ }^{90}$ The perilous nature of the debate helps explain why, after the turbulences in the Görres Society, Grauert preferred to keep silent for a while about the objectivity that he wanted historians to practice. More generally, it helps explain why few Catholic historians of Grauert's generation were inclined to reflect in print on the virtues they saw as conducive to historical knowledge. Although the source-oriented type of work to which most of them devoted their careers can be seen as testifying to Waitz's influence, it can also be regarded as a safe strategy for scholars who preferred to avoid being stigmatized as "liberal" by their fellow Catholics (as happened to Grauert) or as "ultramontane" by their Protestant colleagues (as happened to Hüffer). Mütter, Geschichtswissenschaft in Münster, 262.

${ }^{91}$ K[luckhohn], "Georg Waitz," 4313; "Leopold v[on] Ranke und Georg Waitz +," Zeitung für das höhere Unterrichtswesen Deutschlands, 15 (1886), 179-80.

${ }^{92}$ Wattenbach, "Gedächtnisrede," 10. See also Juan Fastenrath, “Los historiadores alemanes: Leopoldo de Ranke y Jorge Waitz," Revista de ciencias históricas, 5 (1887), 16-21, at 20.

${ }^{93}$ Ferdinand Frensdorff, "Zur Erinnerung an Georg Waitz: Vortrag auf der Versammlung des Hansischen Geschichtsvereins zu Quedlinburg am 15. Juni 1886 gehalten," Hansische Geschichtsblätter, 14 (1885), 1-10, at 10.
} 
Ranke.. ${ }^{\prime 94}$ Apparently, the obituary writers not only shared a language of virtue, but also a desire to position Waitz on an imaginary map of the discipline and to measure his distance from alternative positions, each of which corresponded to a distinct virtue catalog, marked by a name like "Pertz," "Dahlmann," or "Janssen."

These names, to be sure, were highly stylized symbols. As proper names turned into generic names, they were supposed to represent different models of doing history. This schematization is especially clear in the case of Janssen, who was known among Prussian historians as an epitome of "prejudice" or "bias." Thus, when Sybel's former student Hans Delbrück criticized Albert Naudé for using "the Janssen method," this meant that Naudé was guilty of "approach[ing] his material with a preconceived opinion." ${ }^{95}$ Similarly, Schlosser's name was shorthand for "moralism," just as Dahlmann served as a symbol of political history in a patriotic key and hence as a precursor of Prussian School history. ${ }^{96}$ These, of course, were reductionist readings, which as such did not fail to elicit criticism. Carl von Noorden, for instance, argued as early as 1862 that Schlosser had not nearly resembled his "idealized individual distinctiveness" (idealisirten individuellen Eigenthümlichkeit). ${ }^{97}$ Yet, in the context of a protracted debate over what Treitschke called "the first virtues of the historian," the latter that mattered. Schematic readings allowed for clear distinctions between different models of virtue.

\footnotetext{
${ }^{94}$ [Wilhelm] von Giesebrecht, "Georg Waitz," in Sitzungsberichte der philosophisch-philologischen und historischen Classe der k. b. Akademie der Wissenschaften zu München (Munich, 1887), 277-93, at 292.

${ }^{95}$ Hans Delbrück, “Ueber den Ursprung des Siebenjährigen Krieges (Nachtrag)," Preußische Jahrbücher, 86 (1896), 416-27, at 417-18; Max Lehmann, Friedrich der Grosse und der Ursprung des Siebenjährigen Krieges (Leipzig, 1894), 139.

${ }^{96}$ Ottokar Lorenz, "Friedrich Christoph Schlosser und über einige Aufgaben und Principien der Geschichtschreibung," Sitzungsberichte der kaiserlichen Akademie der Wissenschaften: philosophischhistorische Classe 88 (1878), 131-219, at 191; Heinrich von Treitschke, “F. C. Dahlmann,” in Treitschke, Historische und politische Aufsätze vornehmlich zur neuesten deutschen Geschichte, 2nd ed. (Leipzig, 1865), 359-445; Conrad Varrentrapp, “Zur Erinnerung an Friedrich Christoph Dahlmann,” Preussische Jahrbücher, 5 (1885), 485-510; H. Baumgarten, “Dahlmann,” Beilage zur Allgemeinen Zeitung (28 February 1886).

${ }^{97}$ [Carl von Noorden], "Zur Beurtheilung Friedrich Christoph Schlosser's," Historische Zeitschrift, 8 (1862), 11740, at 126.

${ }^{98}$ Treitschke, “Dahlmann," 413.
} 
Accordingly, what was at stake in commemorating Waitz was not only the deceased historian himself, but also, at the same time, the features of a model that admirers and critics alike associated with Waitz - a model that valued criticism over creativity and precision over style. Obituary writers invoked this model not necessarily because they identified with it, but because they considered Waitz's virtue catalog a relevant point of orientation in their own search for what made a good historian. Consequently, their focus was on "Georg Waitz's strongest quality" (qualité maîtresse), as the French historian Jules Zeller put it, ${ }^{99}$ or on the "highest virtue" that distinguished Waitz's model from others, such as those associated with Schlosser, Janssen, and Treitschke.

Could one say, with a term borrowed from Lorraine Daston and Otto Sibum, that Waitz was thereby stylized into a "scholarly persona," which friends and foes alike defined in deliberate contrast to competing personae ${ }^{100}$ If defined appropriately, the persona concept exactly captures what is at stake here. The conditional clause is important, though, as historians in the past decade and a half have employed Daston's and Sibum's concept to rather different uses. As Gadi Algazi has recently argued, "scholarly personae" have taken on at least three different meanings: (1) cultural templates for the codified social role of a "scholar"; (2) scholars' carefully crafted self-images or modes of self-presentation; and (3) embodied images of regulative ideals of what it takes to be a philosopher, historian, or sociologist. ${ }^{101}$ At the first, most general level, scholarly personae denote academic role expectations that can vary across time and place, but are not limited to specific disciplines,

\footnotetext{
99 J. Zeller, “Léopold Ranke et Georges Waitz," Séances et travaux de l'Académie des Sciences Morales et Politiques (Institute de France): compte-rendu, 127 (1887), 430-61, at 460.

${ }^{100}$ Lorraine Daston and H. Otto Sibum, "Introduction: Scientific Personae and Their Histories," Science in Context, 16 (2003), 1-8. Although Daston and Sibum speak about "scientific" personae, the adjective "scholarly" has the advantage of not (unintentionally) invoking a concept of "science" from which the humanities or Geisteswissenschaften are excluded. "Scholarly" thereby does in a 21st-century context what "scientific" did in nineteenth-century ears: it covers the entire range of Wissenschaft. On the conceptual history of these terms, see Denise Phillips, "Francis Bacon and the Germans: Stories From When 'Science' Meant 'Wissenschaft,"” History of Science, 53 (2015), 378-94.

${ }^{101}$ Gadi Algazi, "Exemplum and Wundertier: Three Concepts of the Scholarly Persona," Low Countries Historical Review, 131/4 (2016), 8-32, at 9-16.
} 
schools, or approaches. ${ }^{102}$ At the second, personae are personal and situation-specific products of "self-fashioning," which primarily belong to a scholar's individual biography, even though they draw on culturally sanctioned scripts. ${ }^{103}$ In its third usage, finally, the concept is situated at an intermediate level, between the macro and micro perspectives characteristic of the two previous approaches. At this intermediate level, it refers to such contrastive categories as the "scientific historian" (as opposed to the "unprofessional" or "amateur" history writer), the "archival researcher" (with the armchair scholar as its implied other), and the "funded" academic (a category that as early as the 1940s could be employed against scholars who had never been awarded research grants). ${ }^{104}$

Although the first of these usages probably comes closest to Daston's and Sibum's original intentions, ${ }^{105}$ the third one is most appropriate for our purposes, given how close it comes to how Ranke, Dahlmann, Waitz, and others were invoked as contrastive models of virtue. Named after individuals, but serving as schematic types, these models served as larger than life embodiments of what it could mean to be an historian. With their different prioritizing of historiographical virtues, they served as recognizable "models of scholarly selfhood."106 As such, they were frequently contrasted to each other and invoked by historians in order to map diversity within the discipline as well as to position themselves visà-vis them. Ranke's persona was indissoluble from Schlosser's, just as Waitz's persona could not be conceived without Sybel's, because it was precisely as contrastive models that these

\footnotetext{
102 Henning Trüper, Topography of a Method: François Louis Ganshof and the Writing of History (Tübingen, 2014), 83, 100, 219-21, 232-3, 283, 300.

${ }^{103}$ Mineke Bosch; “Persona and the Performance of Identity: Parallel Developments in the Biographical Historiography of Science and Gender, and the Related Uses of Self Narrative," L'Homme, 24/2 (2013), 11-22; idem, "Scholarly Personae and Twentieth-Century Historians: Explorations of a Concept," Low Countries Historical Review, 131/4 (2016), 33-54.

104 Daniela Saxer, Die Schärfung des Quellenblicks: Forschungspraktiken in der Geschichtswissenschaft 18401914 (Munich, 2014), 140-1, 172; Herman Paul, "The Heroic Study of Records: The Contested Persona of the Archival Historian," History of the Human Sciences, 26/4 (2013), 67-83, at 68-9, 76-7; Pieter Huistra and Kaat Wils, "Fit to Travel: The Exchange Programme of the Belgian American Educational Foundation: An Institutional Perspective on Scientific Persona Formation (1920-1940)," Low Countries Historical Review, 131/4 (2016), 11234.

105 Daston and Sibum, “Introduction,” 2-3; Algazi, “Exemplum and Wundertier,” 11.

${ }^{106}$ Herman Paul, "What Is a Scholarly Persona? Ten Theses on Virtues, Skills, and Desires," History and Theory, 53 (2014), 348-71, at 353.
} 
personae enabled historians to navigate between them and to articulate professional commitments under reference to familiar points of orientation. ${ }^{107}$

Drawing attention to these scholarly personae has a threefold aim. First, it seeks to contribute to a rapidly growing body of scholarship on commemorative activities such as the Waitz-Fest in 1874 and obituaries of the sort examined above. It offers a more diversified explanation of commemorative discourse in nineteenth-century historical scholarship than has been offered previously by pointing out that commemorations were not only celebrations of individual achievements, expressions of professional group solidarity, or attempts at legitimation of scholarly enterprises, but also, and often simultaneously, ways of engaging with models of virtue. ${ }^{108}$ Given that these models were contrastive ones, so that identification with one implied dissociation from others, a focus on scholarly personae brings the polemical subtexts of commemorative discourse more sharply into focus. Scholarly personae did not integrate the field; they represented points of contention.

Secondly, the persona perspective adopted in this article helps contextualize historians' reflections on virtue and vice in their political, religious, and social contexts. As Helmut Walser Smith and others have argued, early Imperial Germany was a nation divided by several fault lines. Most important was the political fault line between the national unification movement spearheaded by Otto von Bismarck and the resistance that this Prussian-dominated project provoked in parts of the Empire where loyalty with the region outweighed identification with Berlin. ${ }^{109}$ When Waitz, born in Flensburg, was hailed as a true son of Schleswig-Holstein or depicted as a praeceptor historiarum for an entire generation of

\footnotetext{
${ }^{107}$ Herman Paul, “The Virtues and Vices of Albert Naudé: Toward a History of Scholarly Personae," History of Humanities, 1 (2016), 327-38.

${ }^{108}$ Vasilios N. Makrides, “Akademische Irrationalismen? Kulte um Personen in wissenschaftlich-akademischen Kreisen," in Alf Lüdtke and Reiner Prass, eds., Gelehrtenleben: Wissenschaftspraxis in der Neuzeit (Cologne, 2008), 261-78; Schnicke, “Rituale der Verkörperung," 347-57; Tollebeek, “Commemorative Practices," 228-9; Kloft, "Nachrufe auf Theodor Mommsen," 283-4. Speaking about an older and different type of obituaries, Catherine Tremain makes a similar argument in "Life After Death: Gender, Idealized Virtues, and the Obituary in Eighteenth-Century Newspapers," in Simon F. Davies and Puck Fletcher, eds., News in Early Modern Europe: Currents and Connections (Leiden, 2014), 175-95.

${ }^{109}$ Helmut Walser Smith, German Nationalism and Religious Conflict: Culture, Ideology, Politics, 1870-1914 (Princeton, NJ, 1995), 61-2; Dan S. White, "Regionalism and Particularism," in Roger Chickering, ed., Imperial Germany: A Historiographical Companion (Westport, CT, 1996), 131-55.
} 
Baltic-German historians, such regionalism manifested itself among historians as a force opposed to especially Treitschke's dream of unifying the German nation by historiographical means. ${ }^{110}$ Overlapping with, but not identical to, this political fault line was the confessional divide between Protestants and Catholics (not to mention the Jewish minority). ${ }^{111}$ When Protestant historians such as Max Lenz scoffed at the "ultramontanism" of their Catholic colleagues, they did so not merely because they perceived Catholics as disloyal to the nation state, but also because they saw membership of a church that blinded itself to Martin Luther's gospel of freedom of conscience as an obstacle for virtues such as impartiality and objectivity. ${ }^{112}$ In social respect, finally, nineteenth-century German historiography had emerged from within the Bildungsbürgertum, which had been its prime audience ever since. When late nineteenth-century historians quarreled over the relative importance of imagination and literary style, this was not only a dispute about the pros and cons of specialization or division of labor, but also, more fundamentally, a debate over social positions and audiences that historians could or should reach. ${ }^{113}$

${ }^{110}$ Kr., "Georg Waitz," Rostocker Zeitung (6 June 1886); Carstens, “Geheimrath," 370-1; B[ienemann], "Gedenkblatt," 511. For historiographical regionalism in these German borderlands, see Uffe Østergård, "Schleswig and Holstein in Danish and German Historiography," in Tibor Frank and Frank Hadler, eds., Disputed Territories and Shared Pasts: Overlapping National Histories in Modern Europe (Basingstoke, 2011), 200-23; Wilhelm Lenz, "'Alt-Livland' in der deutschbaltischen Geschichtsschreibung 1870-1918," in Georg von Rauch, ed., Geschichte der deutschbaltischen Geschichtsschreibung (Cologne, 1986), 203-32.

${ }^{111}$ Christopher Clark, "Religion and Confessional Conflict," in James Retallack, ed., Imperial Germany 1871-1918 (Oxford, 2008), 83-105; Wolfgang Altgeld, "Religion, Denomination and Nationalism in Nineteenth-Century Germany," in Helmut Walser Smith, ed., Protestants, Catholics, and Jews in Germany, 1800-1914 (Oxford, 2001), 49-65; Gangolf Hübringer, “Confessionalism," in Chickering, Imperial Germany, 156-84.

112 The Protestant coloring of these virtues is particularly pronounced in Max Lenz, "Ultramontane Geschichtsscholastik," Politische Wochenschrift, 1 (1882), 262-9. On nineteenth-century views of Luther as an advocate of freedom of conscience, see Heinrich Assel, "The Use of Luther's Thought in the Nineteenth Century and the Luther Renaissance," in Robert Kolb, Irene Dingel, and L'ubomír Batka, eds., The Oxford Handbook of Martin Luther's Theology (Oxford, 2014), 551-72.

${ }^{113}$ Dieter Langewiesche, “Die Geschichtsschreibung und ihr Publikum: Zum Verhältnis von Geschichtswissenschaft und Geschichtsmarkt," in Dieter Hein, Klaus Hildebrand, and Andreas Schulz, eds., Historie und Leben: Der Historiker als Wissenschaftler und Zeitgenosse: Festschrift für Lothar Gall zum 70. Geburtstag (Munich, 2006), 311-26. 
Unsurprisingly, scholarly personae emerged especially in relation to these major fault lines. Sybel is a case in point: he represented political identification with the nation state and as such provided an alternative to Waitz's sharp distinction between historical scholarship and political argument. After Sybel's death in 1895, the "political professor" that he had embodied was discussed as vehemently as Waitz's persona had been in the $1880 \mathrm{~s}^{114}$ Treitschke's death in 1896 unleashed a similar debate about Treitschke's "one-sidedness."115 Likewise, on the confessional fault line, friends and foes alike turned Janssen into a stereotypical model of virtue or vice. ${ }^{116}$ Less emotionally charged, but equally important in mapping the field of historical study were Schlosser's and Dahlmann's personae, which each in their own way represented the time-honored ideal of providing moral and political education to middle class audiences through non-specialized historical writing. Although, by the end of the century, these personae were not seldom depicted as representing a foregone era, they remained attractive to historians who regarded the advance of Waitzstyle professionalism as decline instead of improvement. ${ }^{117}$

\footnotetext{
${ }^{114}$ Conrad Varrentrapp, “Heinrich von Sybel," Biographische Blätter, 1 (1895), 376-91, at 381; Paul Bailleu, “Heinrich von Sybel: Geb. 2. December 1817 zu Düsseldorf, gest. 1. August 1895 zu Marburg," Deutsche Rundschau, 85 (1895), 58-76, at 60-1, 64; Gustav Schmoller, "Gedächtnisrede auf Heinrich von Sybel und Heinrich von Treitschke," Abhandlungen der königlichen Akademie der Wissenschaften zu Berlin aus dem Jahre 1886 (Berlin, 1896), 1-43, at 38; Erich Marcks, “Heinrich von Sybel” (1895), in Marcks, Männer und Zeiten: Aufsätze und Reden zur neueren Geschichte, vol. 1 (Leipzig, 1911), 255-74, at 271-2.

${ }^{115}$ Thomas Gerhards, Heinrich von Treitschke: Wirkung und Wahrnehmung eines Historikers im 19. und 20. Jahrhundert (Paderborn, 2013), esp. 79-80.

${ }^{116}$ For the scorn and hatred that Janssen elicited among Liberal Protestants, see Ludwig Pastor, Johannes Janssen 1829-1891: Ein Lebensbild, vornehmlich nach den ungedruckten Briefen und Tagebüchern desselben, 2nd ed. (Freiburg, 1894), 99-115.

${ }^{117}$ B. Erdmannsdörffer, Friedrich Christoph Schlosser (geb. 17. Nov. 1776, gest. 23 Sept. 1861): Gedächtnissrede zur Feier von Schlossers hundertjährigem Geburtstag am 17. November 1876 in der Aula der Universität Heidelberg gehalten (Heidelberg, 1876), 4; Georg Weber, Friedrich Christoph Schlosser der Historiker: Erinnerungsblätter aus seinem Leben und Wirken: Eine Festschrift zu seiner hundertjährigen Geburtstagsfeier am 17. November 1876 (Leipzig, 1876), vi; Erich Marcks, “Friedrich Christoph Dahlmann” (1899), in Marcks, Männer und Zeiten, vol. 1, 245-53; Friedrich Christopher Schlosser der Geschichtschreiber: Bei Gelegenheit seiner hundertjährigen Geburtstagsfeier (17. November 1876) (Oberhausen, 1876), 5; Franz Rühl, "Friedrich Christoph Schlosser," Nord und Süd, 13 (1880), 350-71, at 353-4; Varrentrapp, "Zur Erinnerung," 501.
} 
If the prism of scholarly personae furthers contextual understanding of scholarly ideals, it finally also encourages researchers to reconsider their long established habit of grouping nineteenth-century historians into schools ("Schlosser school," "Ranke school," "Prussian school of history"). ${ }^{118}$ Compared to this old template, the persona perspective has the advantage of being considerably less homogenizing. For whereas the former tends to locate historians within schools, the latter assumes that historians often found themselves in between models of virtue and, consequently, at carefully calculated distance from, or proximity to, several personae at once. This implies that a focus on personae and their appropriation in the historical field is more inclusive than the conventional school approach. Despite the fact that personae were usually named after famous individuals, their features, functions, and uses come most clearly to the fore in such figures as Weiland and Grauert, who felt themselves torn between irreconcilable commitments, or even in such slightly eccentric historians like Alfred Dove, Otto Seeck, and Robert Pöhlmann, who did not fit any school and therefore navigated even more cautiously between prevailing personae. ${ }^{119}$

\section{Conclusion}

Scholarly personae, understood as clearly delineated models of scholarly selfhood that historians invoked in debates over the virtues most needed for pursuit of historical studies, help explain why Waitz's obituary writers tried to position the deceased in relation to other prominent historians - between Ranke and Dahlmann, closer to Pertz than to Ranke, not as far from Janssen as commonly thought, or in marked opposition to Sybel. Each of these names corresponded to a schematic virtue catalog and thereby to a distinct position in the debate over the marks of a good historian. Placing historians on an imaginary map, between two or more clearly recognizable positions marked by the names of high-profile

\footnotetext{
${ }^{118}$ Classic examples include G. P. Gooch, "The Growth of Historical Science," in A. W. Ward, G. W. Prothero, and Stanley Leathes, eds., The Cambridge Modern History, vol. 12 (Cambridge, 1910), 816-50; James Westfall Thompson, A History of Historical Writing, vol. 2 (Gloucester, MA, 1967), 187-224; Robert Southard, Droysen and the Prussian School of History (Lexington, KY, 1995).

${ }^{119}$ Hans Cymorek, “'...doch reicht mein Einfluß nicht weit': Alfred Dove als Berater Friedrich Althoffs," in Marc Schalenberg and Peter Th. Walther, eds., “...immer im Forschen bleiben”: Rüdiger vom Bruch zum 60. Geburtstag (Stuttgart, 2004), 311-35; Stefan Rebenich, “Otto Seeck und die Notwendigkeit, Alte Geschichte zu lehren," in William M. Calder III et al., eds., Wilamowitz in Greifswald (Hildesheim, 2000), 262-98; Karl Christ, Von Gibbon zu Rostovtzeff: Leben und Werk führender Althistoriker der Neuzeit (Darmstadt, 1972), 201-47.
} 
practitioners, was a way of specifying how the historians in question understood and practiced their vocation. Explicitly or not, such positioning was always a way of selfinscribing, too, if only because judgment on the relative merits of Waitz presupposed a position on the map that did not coincide with Waitz's.

Given that the coordinates on this imaginary map were schematic models of virtue, it is not surprising that quite a few historians tried to stake out intermediate positions. However, in the polarized world that was early Imperial Germany, such negotiation could be fraught with sensitivities. Whereas Weiland only caused surprise when joining Sybel in criticizing Waitz's persona, Grauert provoked fierce protest by softening the contrast between the models associated with Janssen and Waitz. In the binary logic of Catholic opinion leaders shortly after the Kulturkampf, ${ }^{120}$ such consorting with the enemy amounted to betrayal of the Catholic cause. If personae were charged with religious and political meaning, as was the case with Janssen and its non-Catholic "others," attempts to navigate between them incurred risks and costs - which makes it understandable why Catholic historians of Grauert's generation often preferred to keep silent about their preferred personae. $^{121}$

The picture that emerges from examining German historiography through the prism of scholarly personae is, in short, not that of a unified discipline. To the contrary: historians were divided over the virtues they needed, even to such an extent that "disunity" with regard to the historian's vocation seemed to outweigh the sense of a "unified" disciplinary identity. ${ }^{122}$ This is not to say that the historians discussed in this article lacked a common professional space (in the form of journals, conferences, and the like), even though the exclusion imposed upon Catholics and Jews in particular was such that one could make an

\footnotetext{
${ }^{120}$ On which see Christopher Clark, "The New Catholicism and the European Culture Wars," in Christopher Clark and Wolfram Kaiser, eds., Culture Wars: Secular-Catholic Conflict in Nineteenth-Century Europe (Cambridge, 2003), 11-46, at 38-43.

${ }^{121}$ See note 89 above.

${ }^{122}$ As has been argued for fields like biology and high-energy physics by John Dupré, The Disorder of Things: Metaphysical Foundations of the Disunity of Science (Cambridge, MA, 1993); John Beatty, "Why Do Biologists Argue Like They Do?" Philosophy of Science, Supplement 64 (1997), 432-43 and Peter Galison, Image and Logic: A Material Culture of Microphysics (Chicago, 1997).
} 
argument for this space to be contested and divided, too. ${ }^{123}$ Also, disagreement on the historian's virtues does not exclude the possibility of tacit agreement on other issues, such as the importance of archival research, reading skills, or educational practices like the historical seminar. Yet the scale on which historians engaged in historiographical "mapmaking" by positioning both themselves and others between Ranke and Dahlmann, Waitz and Sybel, or other pairs of proper names turned into models of virtue suggests that these scholars themselves experienced their professional environment as characterized primarily by disagreement. Scholarly personae came in the plural because historians in early Imperial Germany found it impossible to agree on the virtues defining a good historian.

\footnotetext{
${ }^{123}$ On academic anti-Semitism in the German Empire, see Notker Hammerstein, Antisemitismus und deutsche Universitäten (Frankfurt am Main, 1995) and, specifically on historians, Carl Misch, "Geschichtswissenschaft," in Siegmund Kaznelson, ed., Juden im deutschen Kulturbereich: Ein Sammelwerk, 2nd ed. (Berlin, 1959), 349-82.
} 